\title{
The Place of "Professional Specialists" on the University Library Staff
}

A growing group within the staffs of university libraries is that of "professional specialist." Persons in these groups may or may not hold library school degrees, but their professional status is assured by special skills, competences, or talents which the library requires and which they present. Examples of "professional specialists" are given; conditions of their appointments, and their job descriptions are enumerated.

$\mathrm{T}$ HIS PAPER IS another in the series of statements drafted by a member of the Committee on Academic Status ${ }^{1}$ of the University Libraries Section of the Association of College and Research Libraries, and approved by the committee as preliminary reports to elicit comment. Readers' reactions are invited and may be sent to the author of this particular paper or to the chairman of the committee. Following possible revisions and final approval by the committee, it is expected to submit all statements to ACRL for endorsement and publication in monographic form.

Within many university libraries there are developing sizeable groups of staff members who may be termed "professional-specialists." This group of individuals seems to be set apart from traditional librarians by shades of difference in their personnel status within the university and within its library. These shadowy variations are the topic of this paper. A description of the professionalspecialist group can be attempted. It

\footnotetext{
${ }^{1}$ Current members of the Committee on Academic Status are R. B. Downs, William H. Jesse, Robert H. Muller, David C. Weber, and Lewis C. Branscomb, chairman.
}

$\mathrm{Mr}$. Weber is Associate Director of $\mathrm{Li}$ braries, Stanford University. cannot, however, be a precise definition when universities achieve such great variance in treatment of similar positions, when assignments may be combined into hybrid positions, and when personnel policies vary widely.

"Specialist" is here used to refer to an individual with a subject or technical expertise combined with a knowledge of libraries and educational institutions. Although most librarians may be said to specialize (for example in law libraries or in cataloging of social science materials), the term is further limited to persons whose specialist talents may be said to dominate his talents as a librarian. Using this definition, there would throughout the country be a rather large number of these positions filled with persons having pursued advanced work in the specialty, while there would be fewer with training in both the specialty and in librarianship. ${ }^{2}$

An indication of the dominating interest in the specialty would be the individual's membership and activity in such associations as the Society of American Archivists, the National Microfilm Association, or the Modern Language Associa-

\footnotetext{
2 There is relevant discussion in Robert B. Downs, "Preparation of Specialists for University Libraries," Special Libraries, XXXVII (September 1946), 209-13.
} 
tion, and perhaps little interest in the American Library Association, the American Association of Law Libraries, or the Special Libraries Association. ${ }^{3}$

Before considering various other ways of arriving at a definition of a distinctive group of positions, the form of the "professional specialist" group may be suggested by the following list of specific specialist assignments which is not exhaustive and will surely in the future include new types.

\section{Administrative or Systems Analyst Archivist \\ Area or Subject Bibliographer \\ Audio-Visual Division Chief}

Book Selection Specialist for a language, subject, or region

Business Manager

Editor of Publications

Information Scientist or Documentalist

Manuscripts Curator

Map Librarian

Paleographer

Personnel Manager

Photographic Specialist

Since some of the specialties, such as work with manuscripts, have been a traditional part of librarianship for centuries, it is clear that any list such as the one above is debatable; and a group of professional-specialists can be described and discussed only in broad generalities subject to all the usual hazards of such treatment.

The term "professional-specialists" is not in general intended to designate librarians with assignments in traditional departments who have become specialized because of the unavoidable division of labor which comes with the increasing size and complexity of the library. The amount of "traditional" librarianship which each specialist practices, and which each must know, is so variable

\footnotetext{
${ }^{3}$ The present use of the word "specialist" is in a different sense from its use in "special librarianship," where an active role in distillation and dissemination of information is implicit, and the meaning is distinctly different from "subject librarian."
}

that this characteristic cannot be used to help define the group.

Taking another approach, there is likely to be a higher incidence of teaching among the professional-specialists than by the traditionally oriented librarians. Courses of instruction offered by librarians who are subject specialists are common in American universities, as they are in those abroad. Others of the above named specialists may also be enlisted for teaching duties in some institutions. Teaching is thus a rather general characteristic of this group, but it cannot serve as a part of the definition for this professional-specialist group, since it is likely to be a voluntary function rather than one inherent in the position held.

Another point of distinction is the special titles often used for these positions, titles assigned to make clear the special assignment which might not be evident from general classification, such as Librarian III or Principal Librarian. A special title may be granted because of the individual's exceptional background, his need for special designation in the community, or the administration's desire for a particular emphasis on the assignment. Thus the head of an audiovisual department may for clarity be called chief of audio-visual facilities, or possibly for emphasis director of academic communications and instructional media. One institution may prefer chief of photocopying services, while another prefers photographer to the library, or specalists for documentary reproduction. Yet here again, titles certainly cannot be used to help define the group.

Professional-specialists may handle either traditional jobs or those rather recently added to the library; or they may direct newly-formed departments or offices. Thus the position of personnel officer may be established as the constant jobs of staff recruitment and training reach proportions requiring that these functions be split off from others. Or new endowment income may serve to create 
a new position with responsibility for archives; and this assignment, combined, for example, with the library's need for a bibliographical study of distinction, may result in the creation of a division of special collections or a department of rare books, archives, and manuscripts, with a chief or a curator to manage it. No one library will have many of each type within this specialist group, but great variations are possible. It must be concluded that the newness or the numbers of such positions do not help clarify the definition.

A close analysis of personnel policies and academic status will produce perhaps the only rather clear sign that a distinctive group does exist. In personnel policies, the professional-specialist may be treated almost exactly as are the librarians, using whatever classification and enjoying whatever academic status are assigned to librarians within a given institution. Yet some differences can be detected, perhaps in salary schedules; or they may lie in eligibility rules for faculty benefits or other indications of status. Where this occurs, the variant treatment is almost certain to be because of their qualifications and services intra muros as professional-specialists, often working especially closely with a department of instruction, rather than because they are librarians "with connections."

As a hypothetical case, an archivist may sit on university committees or be given standing in the university far beyond that of other library department heads when the university considers the archivist in a different light because of the especially important value of his services to the president, trustees, or alumni groups. Or the archivist may have been independent of the library until a recent reorganization; he may have been coordinate with the curator of the museum, the director of the press, or the director of libraries. Further, the business school, or the history and education de- partments, may have a special interest in the organization and use of the archive collection, and may use the archivist to give courses, to sit on committees, and to participate in their academic programs in other ways. The archivist in such an instance may have achieved special privileges by his own activities, competence, and personality combined with a set of local conditions.

Careful analysis of positions in each institution should show where the special nature of the appointment lies; the professional-specialist may by this definition have a slightly different treatment from the majority of librarians in one or another aspect of his employment. These aspects which will be briefly discussed are: the type of appointment, the classification of position, the salary schedule, the question of tenure, the availability of sabbaticals, and other perquisites.

\section{TYPE OF APPOINTMENT}

The specialist may more often work part-time, even less than half-time, than the librarian, who usually holds a fulltime appointment. He may also have jobs outside the university which occupy part of his time. Not infrequently a specialist may hold a joint appointment in the library and in another department of the university, either as an administrator or as a member of the instructional faculty. This mixed appointment for the professional-specialist might mean that he has two forms of status. Since he probably holds academic and perhaps faculty status for his library position, status deriving from another university appointment generally offers no improvement.

\section{Classification}

The professional-specialist will commonly be placed in the classification for librarians, the exact level being determined through job analysis, qualifications for candidacy, experience, and administrative responsibilities. An alterna- 
tive might occasionally be used where the specialist fills one of many similar positions existing elsewhere in the university. Thus, instead of the business manager being inserted into the library classification, he might in some institutions be included in a classification for other individuals having graduate business school training, when he is similar in qualifications to such individuals in the controller's office or business office of the university.

\section{Salary Schedule}

Salaries are one place where the professional-specialist may be treated differently from librarians. The specialist is drawn from a different market which dictates the salary minimums for different levels. This creates a separate salary schedule sui generis. Where the specialist is a librarian who became a specialist by learning on the job, the salary schedules may be identical to that for other librarians. The personnel manager or the map librarian might be examples of this local development. Others may be sought in a national market, such as a documentalist or information scientist, a photographic specialist, or an audio-visual specialist. Once the initial salary is established, the individual may be inserted at the appropriate level in the regular schedule for librarians, with normal increases following, unless the condition of the national market forces more substantial annual increases in order to hold the specialist.

It may be unfortunate that a preferential salary is sometimes determined by the demand and supply on the employment market, but it is unavoidable. Of course, to say that a financial advantage lacks equity with respect to the rest of the professional staff overlooks the fact that the specialist ran the risk of advanced training in a limited field. $\mathrm{He}$ invested time and funds to obtain an education for a field where relatively few people were needed to fill positions in various types of organizations. Fur- thermore, any apparent stretching of salary scales on behalf of the specialist will only tend to bring other librarians along with him for improved salary, status, and benefits.

\section{Tenure}

The part of his appointment in the library would have tenure if librarians are so covered. When the professionalspecialist teaches one or more courses on a regular assignment in a department of instruction, he is not likely to gain faculty tenure for it unless it constitutes the major part of his appointment. In any event, his conditions for job security within the library would almost certainly be the same as those applying to other librarians.

\section{SabBatical Leaves}

As a specialist's job approaches the character of faculty occupations, his sabbatical arrangements should more closely resemble those of faculty than of business officers. That is, the professionalspecialist in a scholarly or academic discipline who has achieved proficiency and a high status among his colleagues is probably able to demonstrate that he could profit from and make good use of a sabbatical leave. Thus some specialists, such as the paleographer, archivist, or book selection specialist, may perhaps be in a more favorable position for a sabbatical than is the typical librarian, though the benefits of sabbatical leaves to all senior librarians can be cogently argued.

\section{Other Perquisites}

The professional-specialist is likely to have a slight advantage over the traditional librarian in such areas as insurance programs, faculty club membership, attendance at faculty meetings with voting power, housing privileges, travel funds, tuition exemption, ticket priorities, and automobile parking arrangements. This comes from the fact that he is a specialist in a minority group and a special case may be made for him 
without opening the flood gates. He may also have special arrangements with one or more departments of the university or with administrative offices which enable him to obtain such privileges.

Although precise qualifications of "professional-specialists" are not possible to define, it may be that from 5 to 20 per cent of the staff of some larger libraries would be specialists as described above. In most libraries it will probably be a smaller percentage. A library which needed specialists in past decades most often found them elsewhere than in library schools. Yet the trend toward employment of specialists has prompted graduate library schools in the past dozen years to organize institutes and to add new courses and combination programs with other departments in the university in order to graduate librarians with better qualifications to handle unusual assignments. ${ }^{4}$ It is clear that graduate library schools are increasingly meeting the need for specialists. Even so, many professional-specialists are not required to obtain a graduate library degree. The educational requirements for holding such a position continue to be highly pragmatic; experience is the best recommendation.

The responsibilities of a few such specific positions and the qualifications sought in these appointments may be suggested in the following examples:

Librarian of East Asian Studies \& Assistant Professor of Library Administration, Ohio State University Libraries. Graduate degree in library science from an accredited library school. Experience in selecting and cataloging East Asian library materials. Scholarly knowledge of the history and literature of the Chinese peoples and to a lesser degree of Japan and Korea. Knowledge of Chinese and Japanese languages.

\section{Coordinator, Library Development}

\footnotetext{
4 See, for example, George S. Bonn, "Training and Education for Information Work," American Documentation, XIII (July 1962), 301-12.
}

Program, University of Tennessee Library. The coordinator for the library development program coordinates the university solicitation of books and manuscripts and money for books and manuscripts. The position requires a college degree, preferably a graduate degree. Teaching and research experience is highly desirable. A library science degree is not required, but would be desirable. A full acquaintance with the teaching and research needs of the institution itself is necessary. A wide knowledge of and enthusiasm for books is requisite.

The Research Associate in Statistical Services, University of Illinois Library. Library degree and some experience, preferably in technical services areas; interest in machine applications to library problems; ability to work well with people and to obtain cooperation from the library staff. Duties are to work with the library administration, departments involved in mechanizing procedures, the statistical services unit, and Advisory Committee on Library Automation; recommend to the library administration specific equipment, programs, and procedures to be followed in the conversion to automation; work out the machine applications and oversee the actual conversion to machine operations of those programs approved by the library administration.

Head of Near Eastern Unit, University of Michigan Library. Has responsibility for the selection and cataloging of all materials in Near Eastern languages to be added to the university library collections, and assists in the acquisition of these materials. Qualifications required are competence in Arabic, a working knowledge of one or more other languages in the area and of two major European languages and several years of library experience, especially with materials from the Near and Middle East and preferably including cataloging of vernacular materials; desirable are grad- 
uate degrees in Oriental studies and library science.

Chief of Administrative Services, Stanford University Libraries. College degree; graduate degree in, or experience in, business administration is considered of major importance; also important is knowledge of audio-visual, photographic, and data processing equipment and similar machine processes important to libraries; and useful is interest in studies of operation efficiency, in printing and publishing, and in building design and equipment. No graduate library school degree required. Minimum of five years experience in business or education is felt necessary.

There is undoubtedly a national trend for an increasing proportion of positions in university libraries to be specialist in character. There are larger numbers of librarians who are full-time book selection specialists or curators of subject collections. Data processing or documentation specialists in university libraries are increasing in number. The use of personnel managers and business managers is increasing. Also audio-visual divisions and photographic departments are now major enterprises in some institutions where they were embryonic twenty years ago.

Dean Neal Harlow foresees that "many competent bit performers in a well ordered system (story tellers, abstractors, technicians, and subject specialists) do not require [the] extended perspective [of librarianship] and need not seek or be granted the freedom of the profession. Persons from allied professional fields, particularly sociology, political science, and technology, will play a major role in the decision-making processes of libraries. ...."

This is a natural result of increasing size and complexity in university libraries. New qualifications are sought in appointments to help solve new problems. Many aspects of work in the larger university libraries can now profit by such specialized attention.

Without resting a conclusion on fact, one may speculate that many types of professional-specialists will remain a part of library organizations in future decades. Some, such as the information scientists, may become absorbed in librarianship. Other specialists (perhaps the business manager and photographic specialist are examples), may always remain a clearly distinct group. One need only consider the officers of the Library of Congress to realize that large research libraries of the future are certain to have on the staff some men who are business specialists, lawyers, historians, as well as other specialists in editing, in communications, in audio systems, or in data processing.

This development is probably a sign of maturity in the library profession. It may result from the fact that libraries are now gaining creditable support in these affluent times.

${ }^{5}$ Neal Harlow, "The Present Is Not What It Was," Library Journal, LXXXIX (June 15, 1964), 2531-32.

\section{Wanted-Choice Editor}

ALA HAS ACCEPTED, with regret, the resignation of Richard K. Gardner as editor of CHOICE, effective January 31, 1966. Mr. Gardner will devote the next several months to completing a doctoral dissertation and, later, will enter upon a career in library education at Western Reserve University.

Persons who may be interested in the position and persons who wish to suggest the names of others who may be interested are requested to communicate with George M. Bailey, executive secretary of ACRL. 